\title{
Review
}

Acta Cytologica 2013;57:316-331

DOI: $10.1159 / 000351159$
Received: April 3, 2013

Accepted after revision: April 4, 2013 Published online: July 12, 2013

\section{Indeterminate and Erroneous Fine-Needle Aspirates of Breast with Focus on the 'True Gray Zone': A Review}

\author{
Nina S. Shabb ${ }^{a}$ Fouad I. Boulos $^{\text {a }}$ Fadi W. Abdul-Karim ${ }^{\text {b }}$ \\ ${ }^{a}$ Department of Pathology, American University of Beirut Medical Center, Beirut, Lebanon; ${ }^{b}$ Department of \\ Anatomic Pathology, Cleveland Clinic, Cleveland, Ohio, USA
}

\section{Key Words}

Breast cancer · Cytologic features · Fine-needle aspirate · Indeterminate $\cdot$ Erroneous

\begin{abstract}
Objective: To review our experience and the literature on inconclusive/erroneous fine-needle aspirates (FNAs) of breast with the focus on the 'true gray zone'. To describe the cytology, differential diagnosis, pitfalls and limitations of common and rare lesions. Study Design: We conducted a literature search focusing on breast FNAs with statistical data of C3 and C4 categories including false-positive and false-negative cases. Similar data from 2003 to 2009 was obtained from our institution. Results: C3 and C4 categories account for $3-17 \%$ of breast FNAs. Contributing factors are technical difficulties, inexperienced pathologists interpreting FNAs of breast and overlap of cytologic features of certain benign and malignant conditions; this last, 'true gray zone' accounts for $2 \%$ of cases. Fibroadenoma, proliferative breast lesions, gynecomastia, infiltrating and in situ lowgrade adenocarcinomas and tubular, cribriform, lobular and mucinous carcinomas are the most common problematic lesions. Granular cell tumor, adenomyoepithelioma, pregnancy-related lesions, fat necrosis, inflammatory and radiation changes, adenoid cystic carcinoma, spindle-cell lesions and
\end{abstract}

Phyllodes tumor are less common. Conclusion: Inconclusive/erroneous FNAs of breast due to the 'true gray zone' are rare. Most are due to the overlapping cytologic features of some benign and malignant conditions. Practical features that may help arrive at the correct diagnoses are elucidated.

Copyright $\odot 2013$ S. Karger AG, Basel

\section{Introduction}

Despite the apparent overall decline in its usage and its replacement by core needle biopsy (CNB), fine-needle aspiration (FNA) of breast continues to play a role in the initial evaluation of breast masses [1-3]. In many settings, FNA remains as accurate as CNB with less cost, complications and shorter turnaround times. The major shortcomings of FNA have been the inability to differentiate invasive from in situ cancer, the unease in interpretation of cytologic specimens among pathologists who are not trained in cytopathology or who do not routinely review these specimens and the presence of an indeterminate/ 'gray zone' category where a definite diagnosis of benign

The original data from the AUBMC was exempt from the local institutional review board; it was considered as QI/QA data.

\section{KARGER}

E-Mail karger@karger.com

www.karger.com/acy
(C) 2013 S. Karger AG, Basel

0001-5547/13/0574-0316\$38.00/0
Correspondence to: Prof. Nina S. Shabb

Department of Pathology

American University of Beirut Medical Center

Beirut (Lebanon)

E-Mail ns04@aub.edu.lb 
or malignant is difficult. We reviewed our experience and the literature of the indeterminate/grey zone category including false-positive and false-negative (FP and FN) cases focusing on those FNAs with adequate and representative material (true gray zone). The cytologic features, differential diagnosis, pitfalls and limitations of the common and rare lesions are elucidated.

\section{Definitions}

Breast FNAs are placed into one of five diagnostic categories according to the uniform approach to breast FNA biopsy [4]:

- C1: Unsatisfactory

- C2: Benign

- C3: Atypical/indeterminate, favor benign

- C4: Suspicious, favor malignant

- C5: Malignant

Categories C1, C2 and C5 are usually straightforward and do not generally pose difficulties to pathologists.

An interpretation of atypical/indeterminate, favor benign (C3) is rendered when the FNA has characteristics of a benign aspirate (C2) but with features not commonly present in benign aspirates. These could be any, or a combination of nuclear polymorphism, some loss of cellular cohesiveness or nuclear and cytoplasmic changes resulting from hormonal or treatment influences. Increased cellularity may accompany the above features [4-6].

The category of suspicious, favor malignant (C4) is reserved for aspirates with some cells with features of malignancy where, however, the material is not diagnostic of malignancy because the specimen is scanty, poorly preserved or poorly prepared. Alternatively, the sample may show some malignant features of a greater degree than those observed in the $\mathrm{C} 3$ category without the presence of overtly malignant cells. Conversely, the sample may have an overall benign pattern with large numbers of naked nuclei and/or cohesive sheets of cells, but with occasional cells showing distinct malignant features [4-6].

An FN FNA is exemplified by an FNA that is classified as $\mathrm{C} 2 /$ benign and shows cancer upon follow-up and/or surgical excision. The incidence of FN breast FNAs ranges from $1-31 \%$ with an average of $10 \%$ [4-6]. The majority of these are due to sampling errors reflecting a quantitative problem in which there are few or no malignant cells on the smear. Quantitating the number of cells required for an adequate sample remains a source of controversy [4-7]. A minority of FNs, however, are due to a qualitative error. In these cases, the malignancies are gen- erally in situ, low-grade or of a special type where malignant cells are present and clearly visible on the slide but are misinterpreted as benign [4-6].

An FNA that is classified as C5/malignant in which there is no malignancy upon follow-up and or surgical excision is categorized as FP. The incidence of FPs in FNA of breast is very low: $0-1 \%$ [4-6]. The most common causes for FP diagnosis are related to the inexperience of pathologists in FNA of breast and benign diseases that have a cytologic overlap with malignant lesions.

\section{Factors Contributing to the Indeterminate/ Erroneous Category}

There are numerous factors that contribute to the indefinite, FN and FP categories. These include: (1) technical difficulties where the smears are limited by cellularity or obscured by drying artifact and or blood, (2) inexperience or unfamiliarity of the pathologist with the cytologic features of breast FNAs and (3) the overlap of cytologic features of certain benign and malignant conditions due to the nature of the lesion (true gray zone) [8-24]. The first 2 factors have accounted for the majority (up to $80 \%$ ) of C 3 and C4 cases whereas the 'true gray zone' represents a small fraction (20\%) [9]. Interpretive categories C3 and C4 should not be abused and should not exceed $15 \%$ of all FNA diagnosis [4]. One major benefit of using the $\mathrm{C} 3$ and $\mathrm{C} 4$ equivocal categories is to reduce the frequency of misdiagnosis in the diagnostic $\mathrm{C} 2(\mathrm{FN})$ and $\mathrm{C} 5$ (FP) categories [4].

\section{Adequacy}

Strict criteria for the adequacy of a breast FNA would result in a decrease in the number of $\mathrm{C} 3$ and $\mathrm{C} 4$ cases. FNAs limited by cellularity and obscuring factors would be better classified as unsatisfactory. The criteria used for adequacy of solid nodules remains subjective. According to the uniform approach to breast FNA biopsy [4], an adequate specimen is one that leads to the resolution of a problem presented by a lesion in a particular patient's breast. There is no specific requirement for a minimum number of ductal cells to be present [7].

\section{Cytologic Features}

The indeterminate categories have cytologic features that fall between clearly benign and clearly malignant aspirates. Benign FNAs are characterized by an adequate sample showing no evidence of malignancy. These samples are usually of low-to-moderate cellularity and consist 
mainly of regular duct epithelial cells with characteristic benign cytologic features in a background of dispersed bare nuclei. Malignant aspirates, on the other hand, are characterized by moderately to highly cellular smears, often with a necrotic background, a monomorphic cell population, a conspicuous loss of cell cohesion, numerous isolated single cells with intact cytoplasm and a variable degree of anisonucleosis. Aspirates that fall into the $\mathrm{C} 3$ and $\mathrm{C} 4$ categories have some characteristics of both benign and malignant aspirates. Cytologic features deemed to be atypical include nuclear crowding, enlargement, overlap and some loss of cohesion [4-6]. Petersen et al. [8] identified certain cytomorphologic features that were helpful in distinguishing benign (atypical) from malignant (low-grade) lesions. Signs of malignancy were cell dissociation, arrangement in small clusters, nuclei greater than $16 \mu \mathrm{m}$, anisonucleosis, irregular nuclear borders, nucleoli and necrosis. Features in favor of benignancy were large monolayers, nuclei less than $16 \mu \mathrm{m}$ without variation in size, smooth nuclear borders and bipolar nuclei in the monolayers.

\section{Statistical Data}

The incidence of $\mathrm{C} 3$ and $\mathrm{C} 4$ as reported in the literature ranges from $3-17 \%[5,6,9-16]$. The highest incidence $(14 \%)$ is found in stereotactic-guided FNAs [12]. Only a few studies clearly separate the causes of difficulty [9-15]. The true gray zone as reported by Al-Kaisi [9] is similar to our experience and represents around $2 \%$ of FNAs.

The proportion of samples classified as $\mathrm{C} 3$ and $\mathrm{C} 4$ varies in different centers. It increases with: (1) inexperience and poor technical skills of the aspirator, (2) inexperience and lack of FNA cytology (FNAC) training of the pathologist and (3) screen-detected/stereotactic-guided biopsies due to the higher incidence of ductal carcinoma in situ (DCIS), low-grade and special-type tumors sampled [11].

The number of cases classified as C3 and C4 are generally equal in most studies, with few studies reporting a predominance of $\mathrm{C} 4$ up to $71 \%$ [10].

\section{Lesions Contributing to the Indeterminate/ Erroneous Category}

Fibroadenoma (FA), proliferative breast lesions [intraductal hyperplasia (IDH) with and without atypia, sclerosing adenosis (SA), radial scar/complex sclerosing lesion (RS/CSL) and papillomas] and gynecomastia in males account for the most common benign lesions, with infiltrating low-grade adenocarcinomas of no special type, tubular, cribriform, lobular and mucinous and lowgrade DCIS being the most common problematic malignant lesions. Less common lesions include granular cell tumor, adenomyoepithelioma, lactation- and pregnancyrelated lesions, fat necrosis, inflammatory and radiation changes, adenoid cystic carcinoma (ACC), spindle-cell lesions and Phyllodes tumor (PT) [8-24].

\section{Is There a Need for Two Separate Uncertain Categories (C3 and C4) or Should They Be Combined into One Equivocal/Suspicious Category?}

Stratification of cases into C3 and C4 is beneficial, according to some experts, in that it identifies groups of patients who are more likely to have either benign (C3) or malignant (C4) outcomes. Large studies with histopathologic correlation have shown that in $\mathrm{C} 3$ category patients, there are benign outcomes in $47-87 \%$, while in $\mathrm{C} 4$ category patients, there are malignant outcomes in $72-87 \%$. A significant proportion of C3 patients, however, still have malignancies (13-53\%), while a smaller percentage of C4 patients have benign disease (13-28\%) [9-15]. Advocates of the 2 categories believe that patients with C3 lesions may not necessarily be subjected to surgical biopsies if their clinical examination and mammography findings are also benign (i.e. a negative triple test). A repeat FNA or CNB may be conducted (after at least 1 month allowing for reactive changes as a result of previous FNA to subside). If the second biopsy is benign (i.e. $\mathrm{C} 2$ and $\mathrm{B} 2$ ), then no surgical intervention or close followup are an option $[10,11]$.

Those that advocate a single equivocal/suspicious category believe that a CNB or surgical biopsy should be done for this combined category as the incidence of malignancy is significant in both subgroups $[13,15]$.

In a survey of preferences among surgeons who routinely use FNAC in their breast cases, there was no strong preference for either a 2 or 1 indeterminate/suspicious category [25].

The following is a discussion of the main categories of breast lesions with emphasis on FNA cytologic features and differential diagnoses. 


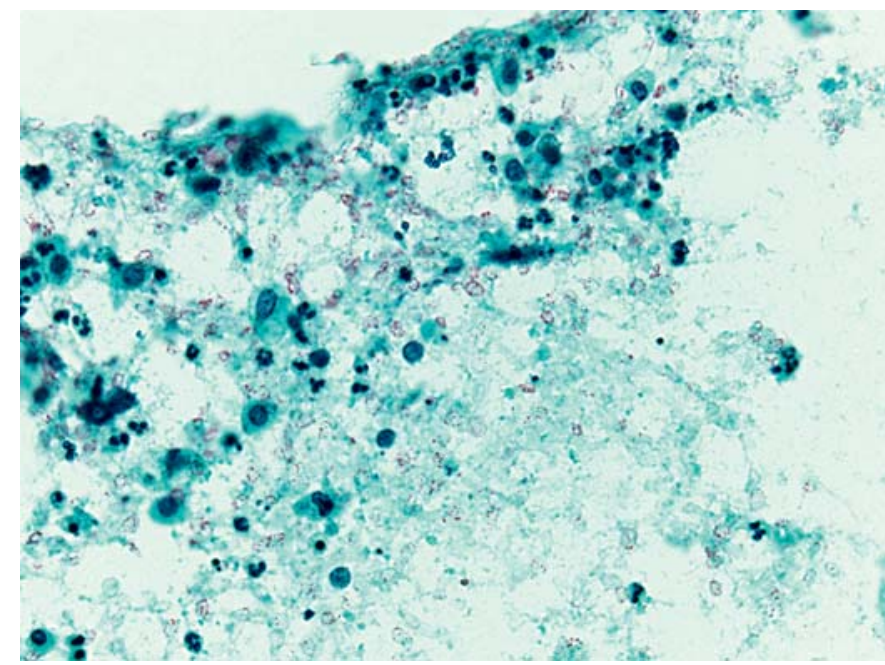

Fig. 1. FNA of fat necrosis: macrophages, neutrophils and crenated red blood cells. Papanicolaou. $\times 40$.

\section{Clinical and Cytologic Mimickers of Malignancy}

Fat Necrosis, Radiation Therapy, Lactation Changes, Granulomatous Mastitis and Granular Cell Tumor

Fat necrosis mimics malignancy, clinically, radiographically and histopathologically. FNA smears from fat necrosis show fat, amorphous debris, inflammatory cells, histiocytes and giant cells (fig. 1). The amorphous debris represents necrotic debris and degenerating fat which impart a foamy, granular and flocculent background. Calcified debris may also be present. The inflammatory cells are polymorphous nuclear leukocytes in the acute phase and lymphocyte and plasma cells in the organizing fatnecrosis phase. The histiocytes have abundant foamy lipid-filled cytoplasm. Multinucleated foreign body macrophages and numerous hemosiderin-laden macrophages may be present. Occasionally, fragments of fibrous tissue and newly found vessels (granulation tissue) may be observed. Epithelial cells are typically sparse but may show nuclear atypia. It is important to be conservative in the interpretation of malignancy when atypical nuclei are present in a degenerative and necrotic background with inflammatory cells and abundant macrophages, as reactive and reparative changes can result in atypia. It is equally important to recognize that the main cellular constituents are histiocytes and fibroblasts rather than epithelial cells [6].

Inconclusive/Erroneous FNAs of Breast: Review

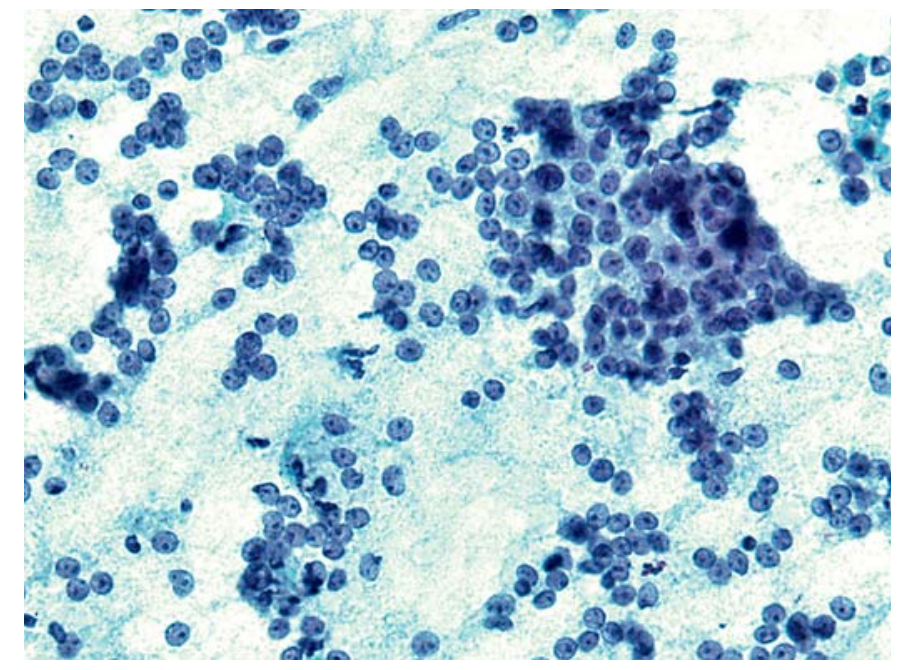

Fig. 2. FNA of lactating adenoma: smears show foamy background material, cells with foamy cytoplasm and round nuclei with prominent nucleoli. Many nuclei stripped of their cytoplasm are noted. Papanicolaou. $\times 40$.

FNA is used in new breast lesions in patients previously treated by radiation and lumpectomy/partial mastectomy to rule out recurrent malignancy. Radiation-induced changes in the breast include epithelial atypia, fat necrosis and poor cellularity. The epithelial atypia can be marked and mimic carcinoma. The most useful distinction from recurrent malignancy is rich cellularity and increased nuclear/cytoplasmic ratios. Loss of cell cohesion, anisonucleosis, conspicuous nucleoli and irregular nuclear membranes are helpful features, but can be seen to different degrees in benign radiation atypia [26-28]. Radiation-induced angiosarcoma is rare and presents as a skin or subcutaneous nodule several years after radiation. A high index of suspicion is a key factor in rendering an accurate diagnosis. Aspirates are usually bloody with spindle pleomorphic cells in a background of arborizing blood vessels. Comparison with the original breast carcinoma is most helpful in recognizing a second primary [6].

FNAC in pregnant and/or lactating women has a higher incidence of FP and FN diagnosis than in nonpregnant/lactating women [29-33]. FP results are due to the fact that the hormonal milieu of pregnancy and lactation leads to epithelial hyperplastic changes with cytologic atypia that can be readily misinterpreted as malignant. The incidence of FN diagnosis is also enhanced by the fact that the index of suspicion is low in this age group. Conversely, malignant tumors with round vesicular nuclei and central prominent nucleoli may be misinterpreted as

Acta Cytologica 2013;57:316-331 


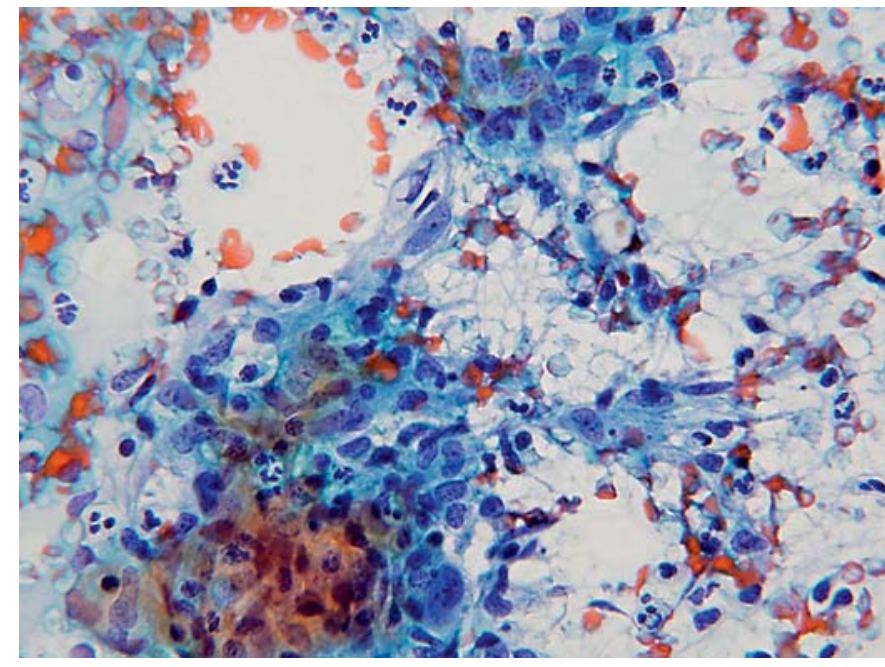

Fig. 3. FNA of granulomatous mastitis: a cluster of epithelioid histiocytes and few neutrophils. Papanicolaou. $\times 40$.

benign pregnancy changes and result in a FN diagnosis. Interpretation of breast FNAC in young women requires heightened awareness of the possibility of pregnant/lactating states; such information may not be routinely provided. The main features distinguishing benign breast conditions from malignancy in pregnancy and lactation are: cellular crowding, overlapped enlarged and pleomorphic nuclei with irregular nuclear membranes, coarse nuclear chromatin, mitoses and cellular dispersion in malignant lesions. Increased cellularity with nuclear atypia, single cells and a dirty background are seen in benign and malignant conditions [29]. Common lesions aspirated during pregnancy in decreasing frequency are lactating adenoma, FA with lactational change, galactocele and infiltrating duct carcinoma. The degree of lactational change varies with the gestational age [30]. Lactating adenomas are described as having moderate cellularity, abundant foamy background material, intact epithelial lobules or acini and small groups and solitary epithelial cells with uniform nuclei, fine chromatin and prominent nucleoli. When present, the cytoplasm is finely vacuolated. Many nuclei stripped of their cytoplasm are present [31,33] (fig. 2). As highlighted by Gupta et al. [32], a team approach with close clinical correlation and follow-up made FNAC in pregnant women as useful as in nonpregnant women.

Granulomatous mastitis is a rare cause of $\mathrm{C} 3$ and $\mathrm{C} 4$ diagnosis [34-39]. It often presents as a mass that mimicks carcinoma clinically and radiologically. It is usually

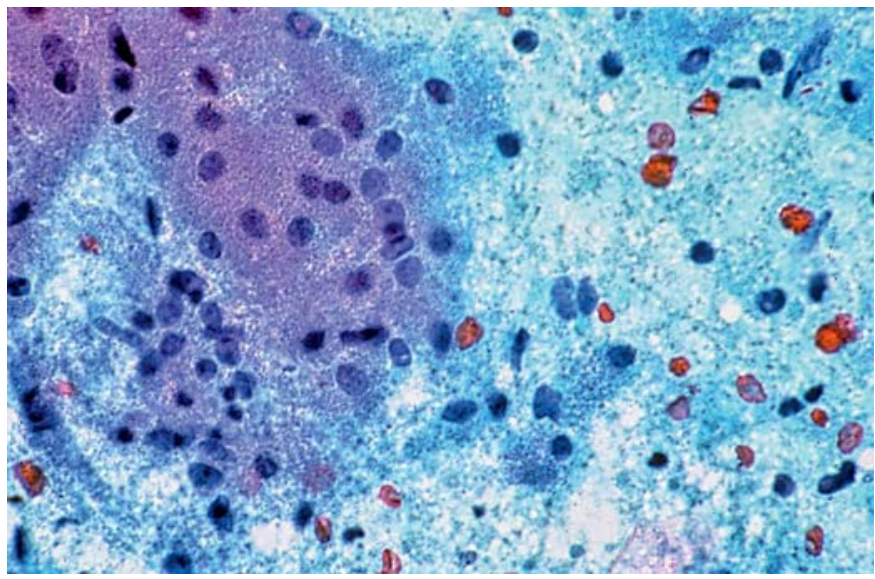

Fig. 4. FNA of granular cell tumor: large polygonal cells with abundant granular cytoplasm, small nuclei with fine chromatin. Papanicolaou. $\times 40$.

idiopathic, associated with lactation or, rarely, may be the result of tuberculosis, fungi, a ruptured epidermal inclusion cyst or a foreign-body reaction to suture or silicone implants. The inflammatory process may be associated with reactive epithelial atypia. Recognition of epithelioid histiocytes, multinucleated giant cells and scattered inflammatory cells help make the correct diagnosis (fig. 3). Correlation with clinical findings and culture are helpful.

Primary granular cell tumors of breast are uncommon and can clinically simulate malignancy. Aspirates are moderately cellular with isolated and clustered polygonal cells with abundant granular, foamy cytoplasm and small nuclei with fine chromatin [40-43] (fig. 4). Positive immunohistochemical stains for $\mathrm{S} 100$ protein and negative staining for cytokeratins and estrogen receptor/progesterone receptor support the diagnosis of granular cell tumor.

\section{Biphasic Tumors}

\section{FA, Benign PT and Adenomyoepithelioma}

FAs account for the largest single cause of false-atypical, false-suspicious and FP cases [8-16, 44-50]. They are most commonly confused with low-grade adenocarcinomas and rarely with PT [51-54]. FNAC of FA is among the most cellular of the benign breast lesions. In the typical aspirates, the smears are cellular and show three elements: stromal fragments, cohesive duct epithe- 


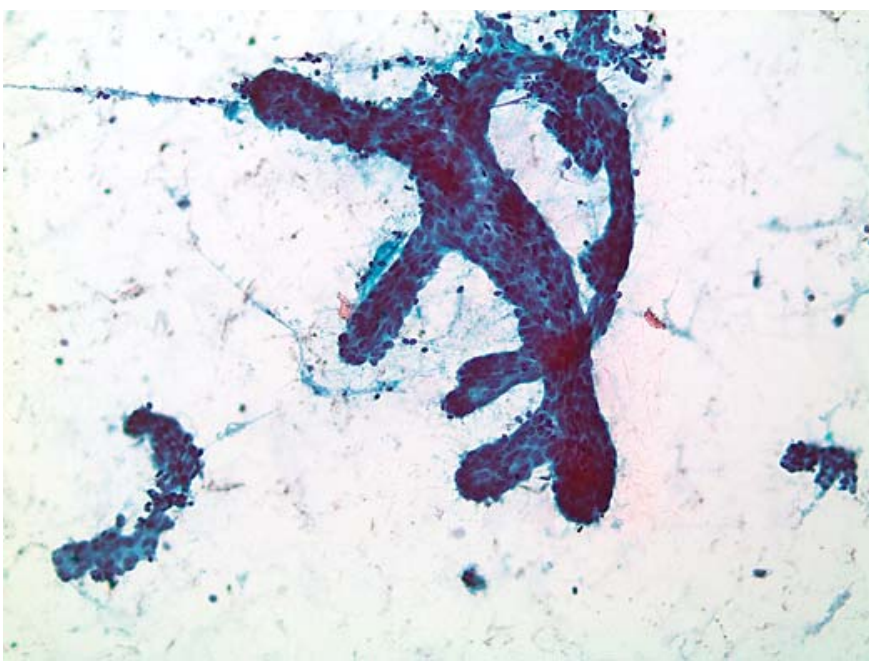

Fig. 5. FNA of FA: tubular structure lacking abrupt change in diameter and pointed ends.

lial cells in large (staghorn) honeycombed, monolayered sheets and myoepithelial (ME) cells overlying the epithelial sheets and evident as single naked nuclei in the background. A mild degree of discohesiveness is commonly observed, i.e. single cells with intact cytoplasm; these should be disregarded when the clinical setting and physical and radiologic findings are typical. Due to the high cellularity, cellular discohesion, nuclear enlargement and prominent nucleoli seen in some aspirates of FA, these can be readily confused with low-grade adenocarcinomas. FAs may also show a few rigid tubular structures similar to those found in tubular carcinoma (TC), but they lack abrupt change in diameter and pointed ends (fig. 5). The epithelial cells of FA are slightly larger than those of normal benign duct cells but not as large as carcinomas. The polarity of the nuclei in the epithelial clusters is preserved in FA, whereas in carcinoma this is lost. The naked nuclei of FA are bland, small and oval; if they are present in carcinomas, they are naked tumor cell nuclei which are larger, more irregular and resemble the nuclei of the surrounding malignant cells. The vast majority of FAs with 'atypia' on FNA are conventional FAs [44]. Fewer cases are attributable to FAs with more complex proliferative lesions such as IDH, apocrine change and SA [44-46]. Conversely, there is also the potential for underdiagnosing breast carcinomas as FA. Intraductal, low-grade carcinomas of no special type and TCs may show stromal fragments and cohesive blandappearing epithelium with small, naked, tumor-cell nu-

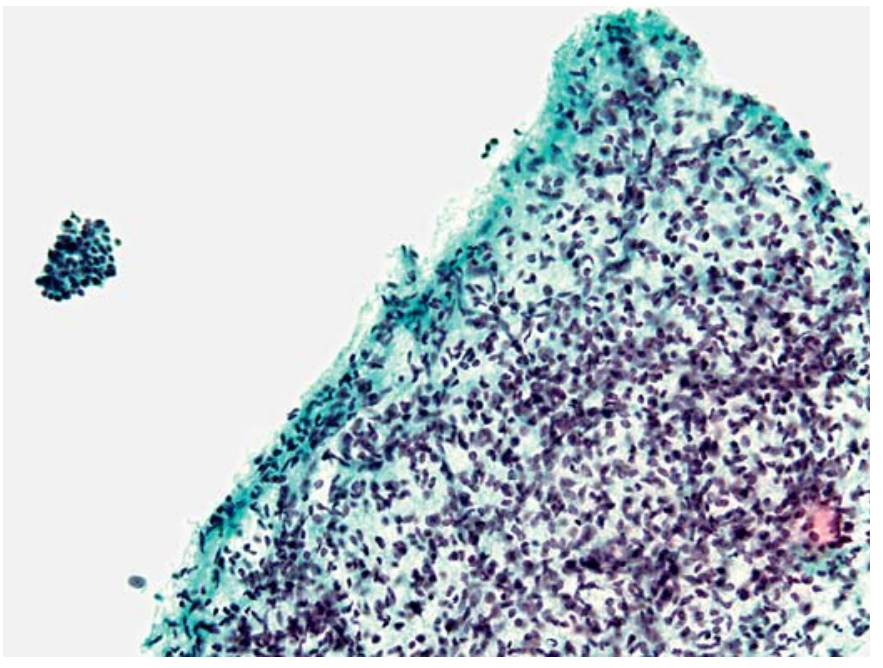

Fig. 6. FNA of benign PT: cellular stromal fragment traversed by blood vessels characteristic of PT but also seen in FAs. Papanicolaou. $\times 40$.

clei mimicking FA. Helpful differentiating features in some cases may be the clinical setting and the feel of the needle while performing the aspirate, rather than the cytology. In general, in young women, well-circumscribed, movable masses in the breast which feel rubbery upon aspiration are more likely to be FAs, whereas in older women, ill-defined, fixed masses with a gritty feel are more likely to be carcinomas. That said, there are cases where the distinction is impossible and an equivocal diagnosis is unavoidable.

Cellular stromal fragments have been used by some to distinguish FA from PT [51] (fig. 6). Many studies, however, have found this to not be reliable due to the variable thickness of the fragments produced by FNA sampling and smearing [52-54]. The presence of blood vessels in the stromal fragments is considered characteristic of PT but may be seen in FA. Significant stromal nuclear abnormality and increased or abnormal mitotic figures are features of malignant PT. On occasion, the epithelial proliferation in $\mathrm{PT}$ can be so extensive as to mimic carcinoma. PT should be suspected over FA when the mass is $>4 \mathrm{~cm}$ and manifests rapid growth. Caution should be exercised in diagnosing carcinoma in the presence of a large, circumscribed mass with stromal hypercellularity.

Adenomyoepithelioma is a rare benign neoplasm of the breast with a biphasic proliferation of epithelial and ME cells. Smears are cellular with large clusters of epithelium and myoepithelium [55-66]. The ME cells can 

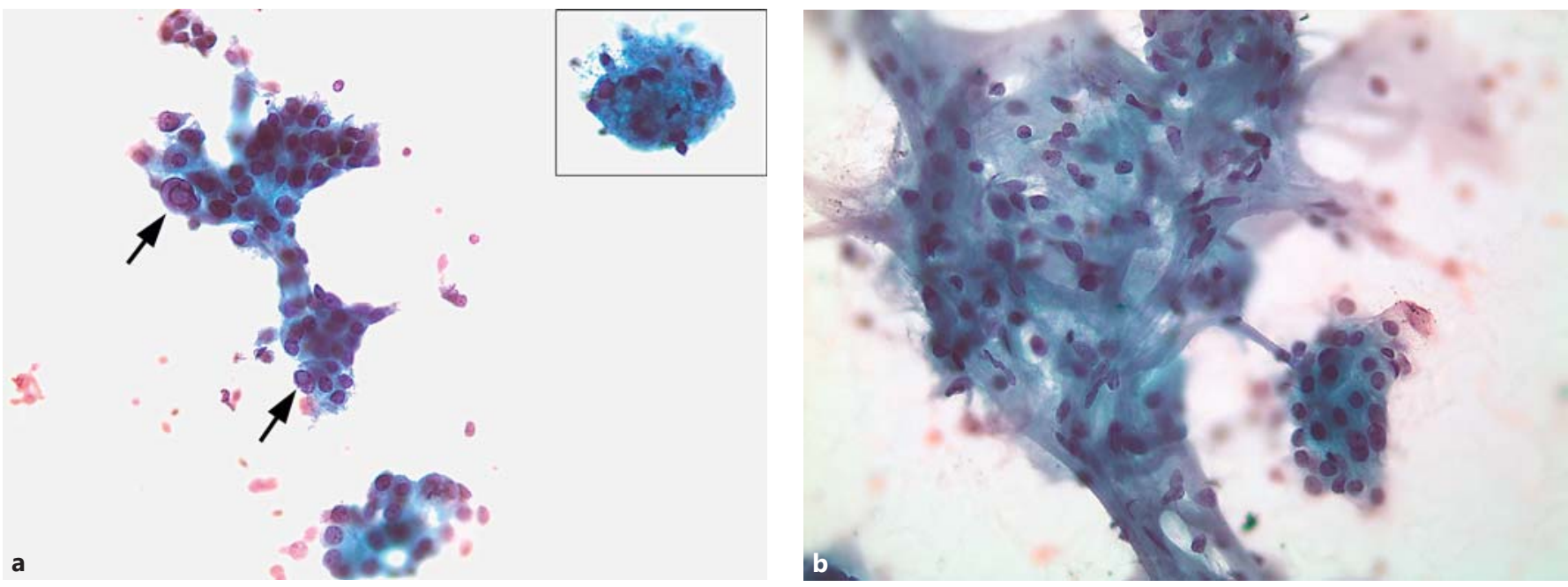

Fig. 7. FNA of adenomyoepithelioma. a Bland epithelial cells surrounded by few ME cells showing enlarged nuclei with intranuclear inclusions (arrows). Inset Epithelioid ME cells with vacuolated cytoplasm mimicking macrophages. Papanicolaou. $\times 40$. b Spindled ME cells. Papanicolaou. $\times 40$.

be difficult to recognize. They are spindled, epithelioid, clear-cell or plasmacytoid. Their vacuolated cytoplasm is best appreciated on the Diff-Quick stain. Intranuclear cytoplasmic inclusions are described in one third of cases (fig. 7). Intranuclear inclusions are not specific to adenomyoepithelioma, but have been described in benign proliferative breast lesions [67], male breast carcinoma [68], myofibroblastoma [69] and myxofibrosarcoma [70]. Mild-to-moderate nuclear atypia is not uncommon and has led to FP diagnosis. To accurately identify the ME cells, immunohistochemical stains such as p63 or smooth muscle actin may be helpful.

\section{Proliferative Breast Lesions}

\section{IDH with and without Atypia, SA or RS/CSL}

Proliferative breast lesions represent the second most common cause of false-atypical, false-suspicious or FP cases in the literature [9-15]. The majority are nonpalpable, mammographically detected lesions, although rarely, they may present as palpable masses. Their cytologic features overlap with those of low-grade carcinomas. The criteria used to diagnose proliferative lesions of duct epithelium in FNAC are similar to those used in histology and include architectural and cytologic features. Sneige and Staerkel [71] found that these features are well represented on aspiration smears. FNAC of IDH without atypia is characterized by epithelial cell groups with complex cellular arrangements and irregular intercellular spaces with adjacent cellular streaming or nuclear spindling. The cells may vary in size and shape with a bland chromatin pattern. Single cells with intact cytoplasm are rare. Low-grade ductal carcinomas, on the other hand, are characterized by a monomorphic cell population of small-to-intermediate epithelial cells arranged singly or in clusters. Cell clusters are usually 3-dimensional with a papillary, solid or cribriform (regular round/ oval spaces with surrounding, uniform, rounded cells) pattern. Individual cells are polygonal or cuboidal with round-to-oval nuclei and occasional small nucleoli [7179]. ME cells within epithelial clusters and in the background are usually absent. Atypical duct hyperplasia is difficult to recognize on FNA smears and shows features common to IDH and low-grade ductal carcinoma [7779]. This reflects the same difficulty encountered in histology. SA and RS/CSL are usually small, mammographically detected lesions; however, when confluent, they may present as a palpable, poorly delineated mass. The cytologic features of SA are characterized by variable cellularity, small-to-large groups of bland epithelial cells that focally form cohesive groups/tubules or occasionally discohesive clusters and individual cells. Acinar sheets are found in most cases. Cohesive, ball-like clusters of proliferating ductules admixed with dense connective tissue are usually seen. The stromal component consists of characteristically small, dense, hyalinized, fibrous fragments occasionally attached to the epithelial 

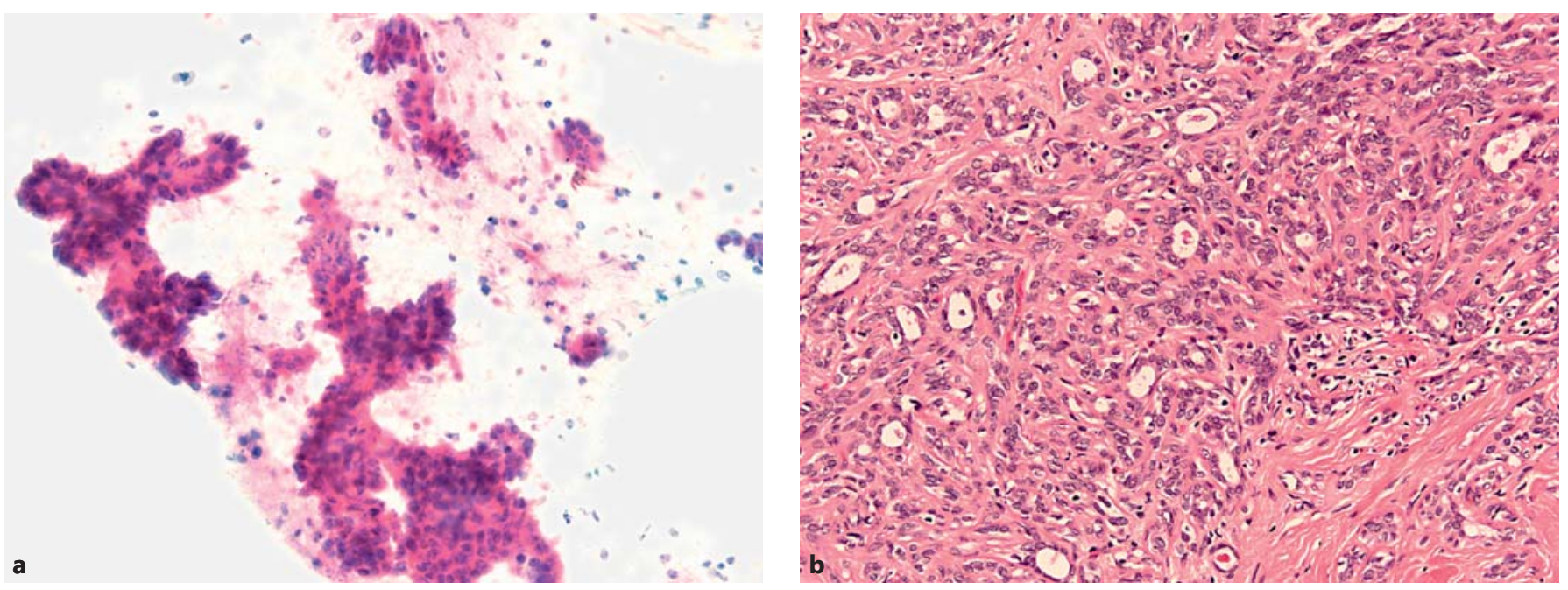

Fig. 8. FNA of SA. a Tubular structures with bulbous ends and background ME cells. Papanicolaou. $\times 40$. b Corresponding surgical pathology. HE. $\times 40$.

sheets. Some tubules have an angulated configuration mimicking TC. ME cells are present in the background, but are not always associated with the small epithelial fragments (fig. 8) [80, 81]. Difficulty arises when aspirates show atypical features such as angulated tubules, discohesive individual cells, scant ME cells and nuclear atypia being noted concurrently [80]. Tubules with an angulated configuration or pointed ends, seen in SA, are usually a feature attributed to TC. TCs are more frequently hypercellular and the abnormal tubules are more abundant and diffuse and have a more rigid outline or acutely angled configuration. Discohesive cells are also more abundant [82-86]. Single cells with intact cytoplasm could mimic lobular carcinoma. In a large study of FNAC of RS/CSL [87], a C3 or C4 diagnosis was rendered in more than half the cases. RS/CSL were cytologically characterized by a mixed cell picture in which bipolar, naked nuclei, large and small cohesive epithelial sheets, apocrine cells, foam cells and elastoid stromal fragments were seen in various degrees. Papillary clusters, calcifications and tubular structures without rigid configuration associated with ME cells were also described. High cellularity, dirty background, tubular structures and dyshesion has led in some cases to the $\mathrm{C} 3$ and $\mathrm{C} 4$ diagnosis. The cytologic features are not specific and a diagnosis of RS/CSL can only be suggested when taking into consideration the radiologic appearance of the lesion [87-92].

Inconclusive/Erroneous FNAs of Breast: Review

\section{Mammary Carcinoma and Its Variants}

\section{DCIS, TC, Invasive Ductal, Cribriform, Lobular and ACC}

Ductal adenocarcinoma, no special type and of low nuclear grade accounts for the most common cause of FN, falsely atypical and falsely suspicious cytology diagnosis due to its common occurrence. Similar to the higher-grade counterparts, the smears are cellular with conspicuous loss of cell cohesion, scattered, individual tumor cells with intact cytoplasm and aggregates of 3-dimensional clusters, syncytial groups or occasional gland-like arrangements. Nuclear enlargement and atypia, by definition, are minimal [4-6].

High-nuclear-grade DCIS is readily diagnosed as malignant on FNAC. Low-nuclear-grade DCIS is problematic and is characterized by moderate-to-high cellularity, monomorphic, uniform, neoplastic cells with cribriform, solid or micropapillary patterns. The absence of ME cells helps distinguish it from benign proliferations. A distinction between invasive low-nuclear-grade carcinomas and in situ lesions is not possible [71-79].

The diagnosis of TC by FNAC is difficult with less than $50 \%$ of cases classified as C5 [82-86]. The characteristic findings include tubular structures, noteworthy dissociation, paucity of myoepithelium and cellular atypia [86]. The tubules in TC are usually numerous, rigid and with an abrupt change in diameter often ending in pointed tips (fig. 9a). They have abnormal angles with duct arms going 

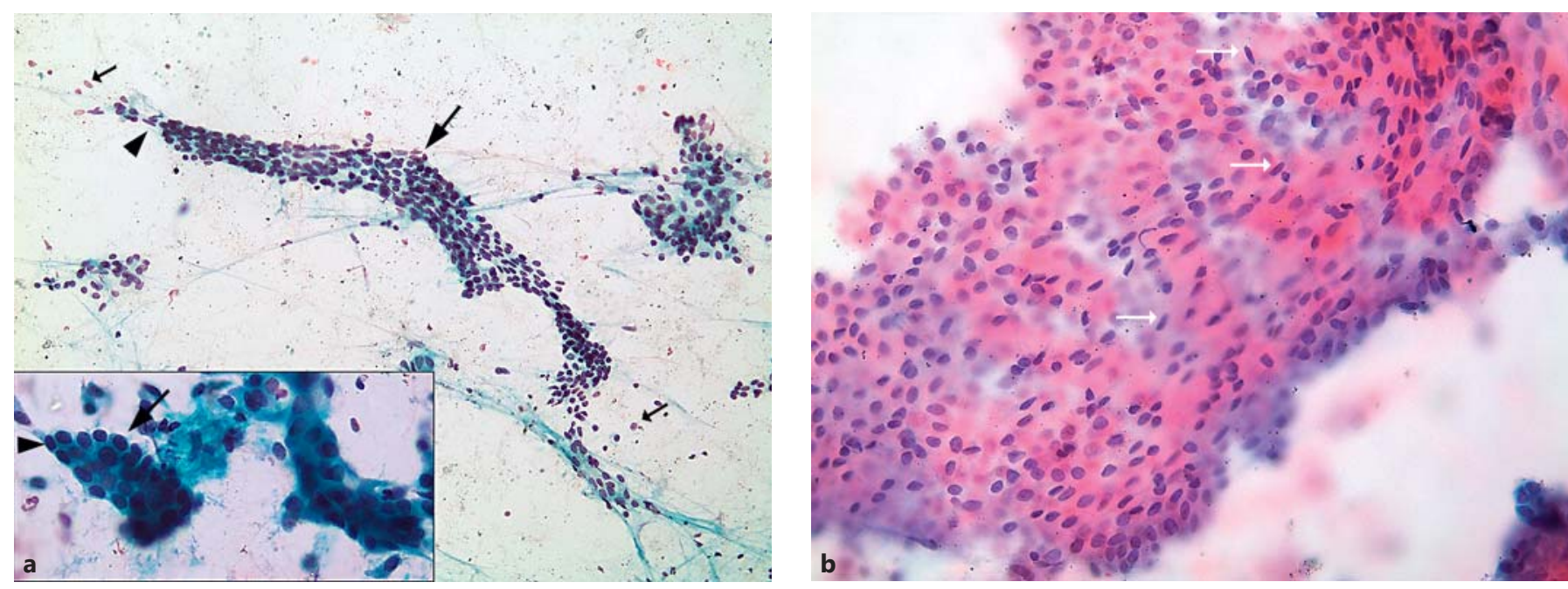

Fig. 9. FNA of TC. a Rigid tubules with abrupt change in diameter (long arrows) ending in pointed tips (arrowheads). Few stripped ME cell nuclei in background (short arrows). Papanicolaou. $\times 40$. $\mathbf{b}$ ME cell nuclei seen on a plane above a cohesive group of epithelial cells (white arrows). Papanicolaou. $\times 40$.

off in unexpected directions at branching spots and are sometimes even without branching, resembling a bent elbow. Tubules may also have coma-shaped projections. Fibrillary stromal aggregates, intracytoplasmic vacuoles resembling those of lobular carcinoma and the presence of nuclear grooves are helpful diagnostic criteria. ME cells may be numerous (fig. 9b). It is the presence of numerous ME cells, minimal dissociation and lack of significant cytologic atypia in some cases that results in an FN diagnosis of FA. Rigid tubular structures can be seen in FAs; however, FAs usually have a more prominent ME component, less discohesion and no/minimal cytologic atypia. Aside from the cytologic differences, the distinction becomes clearer when the pathologist performs the aspirate and can assess the difference between the gritty carcinoma and the rubbery FA.

The diagnosis of cribriform carcinoma is difficult on FNAC due to the relative cohesive nature of the malignant epithelium and the low nuclear grade [93-96]. Key to arriving at the correct diagnosis is recognizing cribriform as opposed to honeycombed architecture in the large sheets, absent-to-sparse ME cells and low nuclear grade. Osteoclast-like giant cells have been described more commonly in invasive cribriform carcinoma, although they have also rarely been reported in the in situ counterpart (fig. 10). Their presence should raise the suspicion for invasion [93-96].

Classic lobular carcinoma is associated with the highest FN rate among all types of mammary carcinoma. This

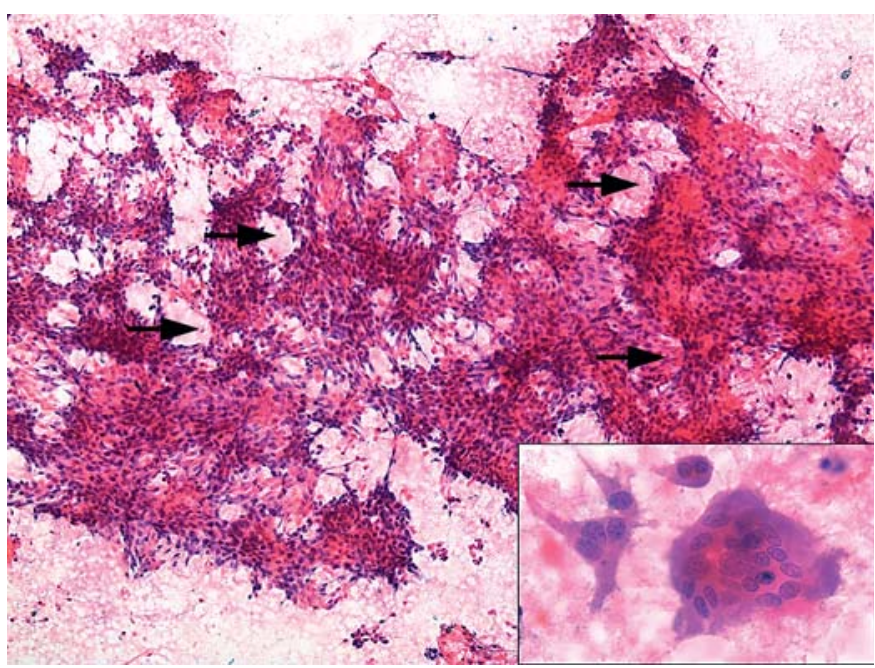

Fig. 10. FNA of invasive cribriform carcinoma: large sheets of cohesive epithelium with cribriform (cookie-cutter) architecture (arrows). Papanicolaou. $\times 20$. Inset Osteoclast-like giant cell more commonly seen in invasive carcinoma. Papanicolaou. $\times 40$.

is either due to sampling error related to paucity of tumor cells as a result of associated desmoplastic stroma or interpretive errors due to small cell size and subtle cytologic atypia of the tumor cells. FNAC slides are of variable cellularity. The cells are small and uniform with small nuclei. They present as single cells, Indian files or small balls. 


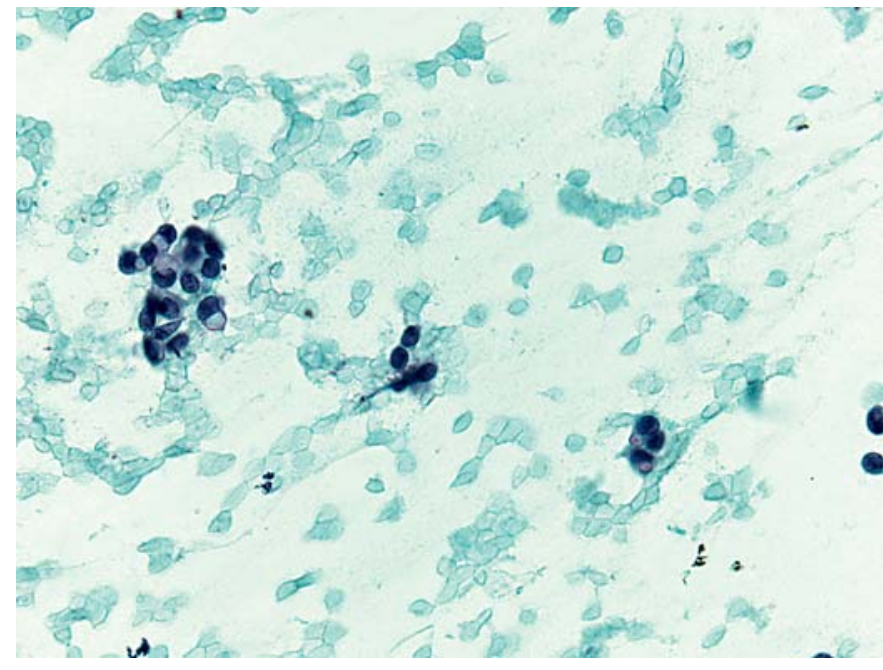

Fig. 11. FNA of invasive lobular carcinoma: small tumor cells with eccentric nuclei and intracytoplasmic lumina. Papanicolaou. $\times 40$.

Eccentric nuclei and occasional intracytoplasmic lumina with mucin droplets are characteristic. Cytologic atypia is insignificant (fig. 11). The monomorphic pattern and absence of ME cells are key features to differentiate it from benign breast lesions. The clinical and radiologic findings and the gritty feel of the needle while aspirating are also helpful features [4-6].

ACC is rare ( $<0.1 \%$ of breast malignancies). It is often subareolar and well circumscribed, mimicking FA. The most defining features are the solid, homogeneous, acellular, cylindromatous spherules (most conspicuous as metachromatic and magenta on the Diff-Quick stain and gray-blue on the Papanicolaou stain). These are surrounded by 3 -dimensional, uniform epithelial-cell clusters with scant cytoplasm, bland nuclei containing fine chromatin and scattered single cells similar to those in the clusters [97-100] (fig. 12). The cytologic differential diagnosis includes collagenous spherulosis, pleomorphic adenoma and metaplastic carcinoma (MC). Aspirates of collagenous spherulosis demonstrate amorphous hyaline globules, but the cells are arranged in 2-dimensional sheets with a lower N/C ratio and naked, bipolar nuclei are seen in the background. Aspirates of pleomorphic adenoma also contain metachromatic material, but this is more fibrillary with irregular feathery outlines compared to the metachromatic spheres of ACC. The cells are bland with ovoid and spindle nuclei. MC may have metachromatic stroma, but the cells show significant cytologic atypia not seen in ACC [97].

Inconclusive/Erroneous FNAs of Breast: Review

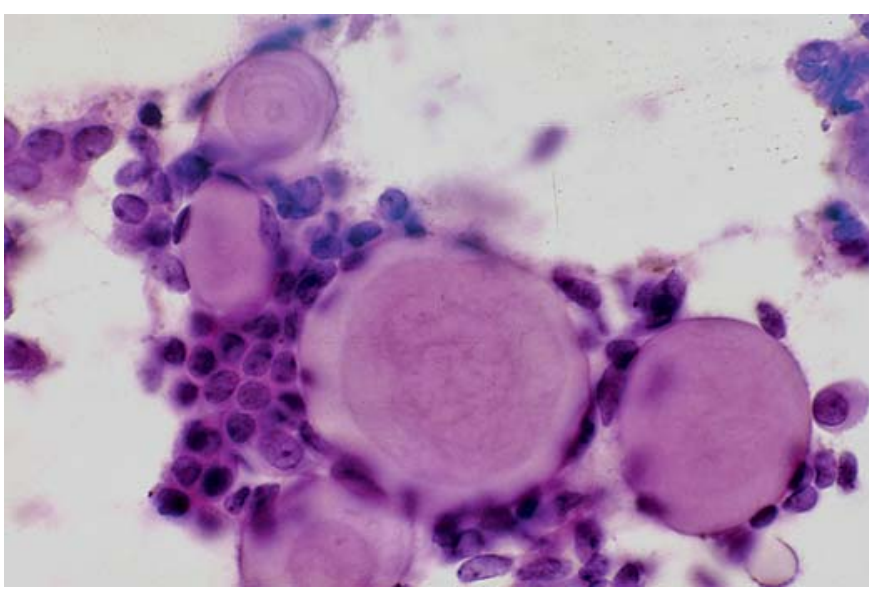

Fig. 12. FNA of ACC: homogeneous, cylindromatous, acellular spherules surrounded by uniform epithelial cell clusters with scant cytoplasm and bland nuclei. Diff-Quick. $\times 40$.

\section{Mucinous Neoplasms and Lesions}

Mucinous Carcinoma and Mucocele-Like Lesions

Aspirates of mucinous (colloid) carcinoma are usually cellular, consisting of monomorphic cells in an abundant extracellular mucinous background. The tumor cells may be arranged in 3-dimentional groups with smooth, rounded contours, monolayered sheets or as numerous isolated cells. They are generally uniform, bland-appearing with a wispy, microvesicular cytoplasm (fig. 13). The finding of diffuse cytoplasmic hyalinization with resulting eosinophilia has been described as characteristic of mucinous carcinoma. Their nuclei are eccentric, with uniform vesicular chromation. Nuclear pleomorphism is minimal. Nucleoli are small and inconspicuous [101105]. The finding of significant pleomorphism and necrosis indicates the presence of a mixed carcinoma. The background mucin has a stringy appearance that may have focal linear strands of filmy streaks or globes. It stains blue-green on Papanicolaou stain or bright pink on Diff-Quick. It can be highlighted by PAS, Giemsa or Alcian blue stains. Fibroblast and branching, thin-walled blood vessels are often included in the mucin [4-6].

Aspirates from mucocele-like lesions also yield abundant extracellular mucin. These lesions are hypocellular, however, and generally consist of flat sheets of cohesive epithelium and a few scattered histiocytes and fibroblasts. Unlike mucinous carcinoma, individual epithelial cells are rare or absent. Aspirates from mucinous carcinoma 


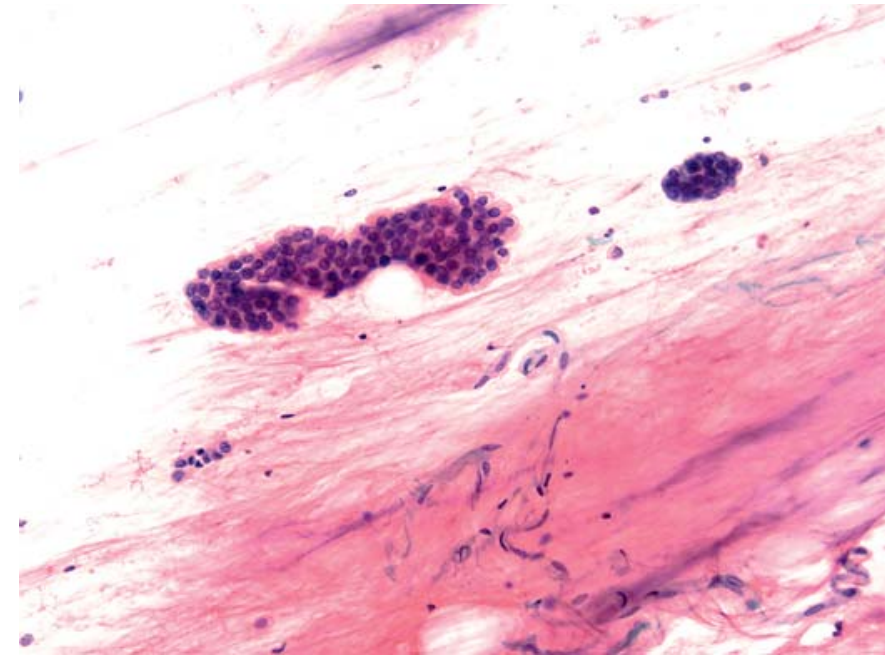

Fig. 13. FNA of mucinous carcinoma: 3-dimensional groups of low-grade carcinoma cells in a mucinous background. Papanicolaou. $\times 40$.

that are very hypocellular and devoid of cytologic atypia or those associated with atypical ductal hyperplasia can be indistinguishable from mucocele-like lesions. For all such aspirates, an interpretation of 'mucinous neoplasm or lesion' is appropriate and an excisional biopsy is recommended [6].

Mucinous carcinoma frequently simulates myxoid FA, clinically and cytologically. FAs generally occur in younger patients than do mucinous adenocarcinoma. Unlike mucinous carcinoma, FA demonstrates the presence of stroma, staghorn groups of ductal epithelium and ME cell components (numerous bare, bland, bipolar nuclei in the background).

\section{Papillary Neoplasms}

\section{Intraductal Papilloma and Intracystic Papillary \\ Carcinoma}

Intraductal papillomas share many of the features of benign lesions of the breast, but their characteristic cytologic/histologic feature is the arborescent papillary growth of epithelial cells surrounding a fibrovascular core [106-109]. Despite this definition, a number of potential issues arise when dealing with a seemingly papillary proliferation on FNA. First, a papillary-like architecture can be seen in a number of benign and malignant nonpapillary proliferations. In their study, Simsir et al. [106] were able to confirm the diagnosis of true papillary prolifera- tion in only 31 of 70 FNAs diagnosed as papillary neoplasms. The cases that were misdiagnosed varied from FA to DCIS to invasive ductal carcinoma. The features they found to be most helpful in clarifying this differential were: smear cellularity, nuclear pleomorphism and the presence of cytologically bland, columnar cells. Still, some cases failed a clear-cut distinction and categorization even after retrospective review. According to Michael and Buschmann [107], distinguishing true papillary from papillary-like proliferations is possible when the cytopathologist pays close attention to the presence of true fibrovascular cores covered by columnar cells and to large sheets with ruffled borders and small tongue-like projections, rather than bulbous and architecturally complex epithelial fragments with finger-like projections without true fibrovascular cores. One additional feature this paper described was the relative abundance of ME, naked nuclei in FAs relative to papillary tumors, and the complete absence of apocrine metaplasia in carcinomas as opposed to benign papillomas. Other papers have highlighted another element of potential confusion, namely the occasional infarction of papillomas and the resultant potentially significant reactive atypia $[108,109]$. The presence of ghost cells, infarcted papillary fragments, degenerate columnar cells, extensive necrosis and squamous metaplasia may be helpful in such cases. Our stance towards papillary lesions is one compatible with the cautious attitude facing a diagnosis of intraductal papilloma on $\mathrm{CNB}$, and emphasizes the need for surgical excision. Distinguishing a true papillary lesion from FA is probably the more relevant issue, and should be possible in the majority of cases, in order to avert an unneeded surgical excision.

Distinguishing a benign from an atypical/malignant papillary proliferation is an area of much contention, given the significant overlap in cytologic features $[110,111]$. The most frequently quoted differential features favoring malignancy are: high cellularity, thin, single fibrovascular cores and complex branching patterns, discohesive cells with variable degrees of cytologic atypia (fig. 14b) and the absence of bland, bipolar and benign apocrine cells in the background $[108,112]$. Despite the presence of helpful features favoring benign versus atypical/malignant papillary lesions, no single feature is pathognomonic for one entity versus another. In our experience, we have encountered cases with numerous, background, oval, naked nuclei compellingly suggestive of ME cells in papillary lesions with mildly atypical features that showed papillary carcinoma on follow-up surgical excision. We therefore maintain that the presence of a credible papillary pattern on cytology should prompt further intervention, either 

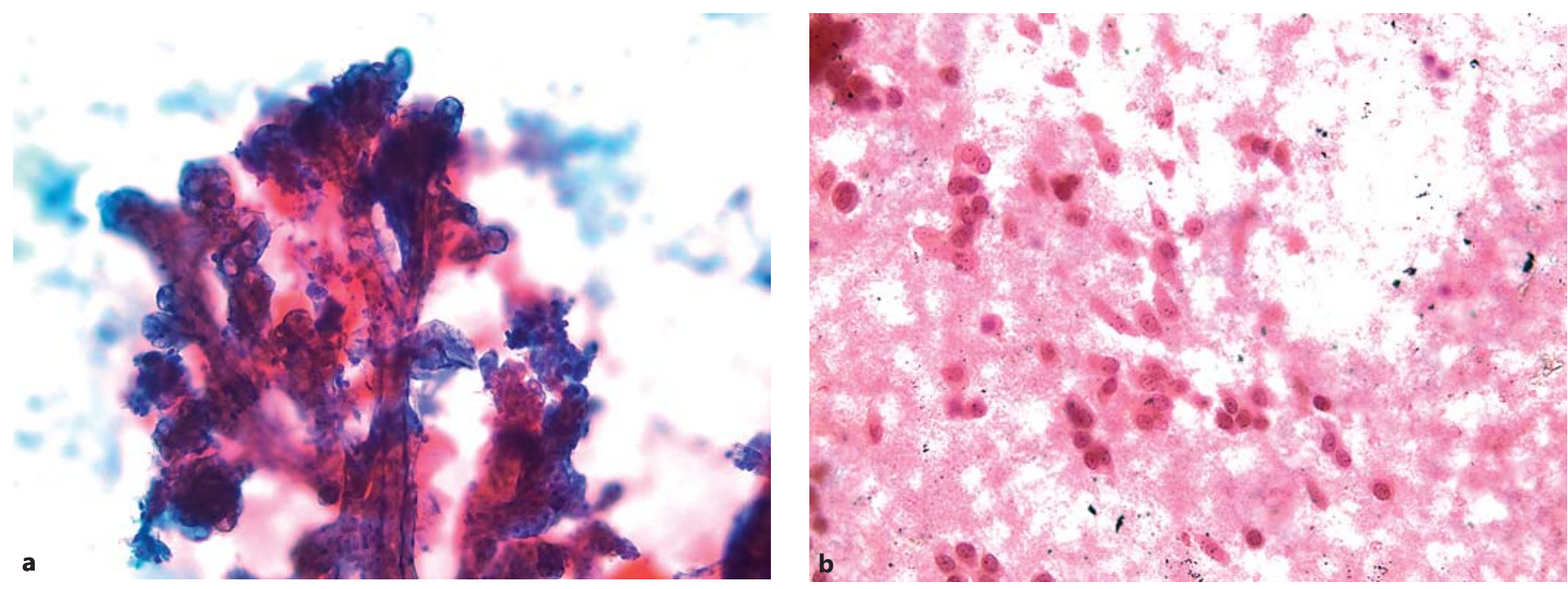

Fig. 14. FNA of papillary lesions. a Fibrovascular cores forming true papillae. Papanicolaou. $\times 40$. $\mathbf{b}$ Discohesive low-grade tumor cells with intact cytoplasm in a case of intracystic papillary carcinoma. Papanicolaou. $\times 40$.

CNB or formal surgical excision. Correlation of the cytologic findings with clinical and radiographic information should also facilitate management decisions.

\section{Benign and Malignant Spindle-Cell Lesions}

\section{Myofibroblastoma, Fibromatosis, MC and Malignant PT}

Though rare, spindle-cell lesions of the breast comprise a large number of entities, spanning reactive to benign to locally aggressive and frankly malignant proliferations. Despite the divergent biologic behaviors of different tumors, cytomorphologic overlap is often significant, and any attempts at definitive classification of spindle-cell lesions based on cytology alone should be met with a healthy degree of skepticism [113]. The benign spindle-cell lesion most likely to lend itself to an accurate diagnosis is myofibroblastoma in its classic form. Myofibroblastoma's most salient features include oval-shaped discohesive tumor cells with evenly dispersed chromatin, inconspicuous nucleoli, mild pleomorphism, occasional nuclear grooves and intranuclear cytoplasmic pseudoinclusions and collagenous bundles [114]. Myofibroblastoma can, however, show a wide variety of morphologies and may exhibit high cellularity, marked pleomorphism, epithelioid morphology and mucinous stromal change, significantly complicating its cytologic diagnosis [115]. Other complicating factors in the diagnosis of benign spindle-cell tumors is the minimal atypia and low cellu- larity present in potentially aggressive/malignant neoplasms such as fibromatosis and fibromatosis-like MC. A peculiar reactive mesenchymal tumor seen following invasive procedures is the postoperative spindle-cell nodule [116]. Because of their high cellularity and proliferative activity, these lesions can be worrisome on cytology. Knowledge of the clinical circumstances, namely prior manipulation and rapid unexplained growth, paired with the absence of significant hyperchromasia and nuclear irregularity and a conspicuous inflammatory and hemosiderotic background can assist the pathologist in rendering a correct benign diagnosis [117]. We reemphasize the extreme caution pathologists should exercise when dealing with mammary spindle-cell lesions. In cases where an adequate cell block is available, cytokeratin and p63 (for $\mathrm{MC}$ ), desmin and CD34 (for myofibroblastoma) can be invaluable in establishing or excluding a specific diagnosis.

Highly atypical spindle-cell tumors generally pose little diagnostic challenges, and a diagnosis of malignant spindle-cell neoplasm can be readily made. The exact nature of the malignant spindle-cell neoplasm will, however, often defy more precise classification, especially without the assistance of histology and immunohistochemical evaluation. While primary breast sarcomas are exceedingly rare, malignant PTs with stromal overgrowth and metaplastic spindle-cell carcinoma represent the most common malignant spindle-cell lesions of the breast. The presence of a conspicuous, benign (albeit proliferative), epithelial component would favor a PT, while a biphasic 


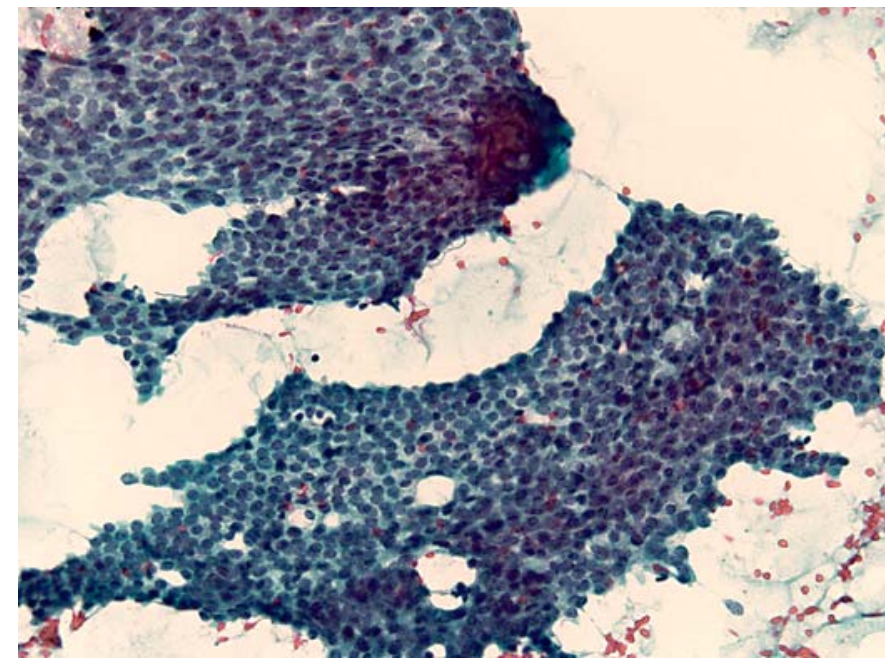

Fig. 15. FNA of florid gynecomastia: cellular smears with fragments of hyperplastic duct epithelium. Papanicolaou. $\times 40$.

epithelial/mesenchymal phenotype or the presence of malignant squamous differentiation would favor a MC [118-120]. When dealing with a purely sarcomatoid proliferation, the distinction between PT, MC or primary mammary sarcoma becomes immaterial as all three neoplasms mandate wide surgical excision without the need for axillary lymph node dissection in the absence of a clinically positive axilla [121].

\section{Breast Masses in Males}

Male breast masses are uncommon. The vast majority are benign (gynecomastia), while a few (5-12\%) are due to either primary or metastatic malignancies. Florid gynecomastia has been the cause of false-suspicious and FP cases in the cytology literature $[122,130]$. It is characterized by epithelial hyperplasia, both flat and micropapillary, often associated with ME cell proliferation and increased stromal cellularity (fig. 15). The fibrous/inactive phase of gynecomastia occurs later, has less epithelial hyperplasia and increased stromal collagen and is therefore less problematic on FNAs. FNAC of gynecomastia has been described as having hypocellular-to-moderately-cellular smears, cohesive sheets of bland duct cells, scattered ME cells and few spindle cells. Duct epithelial atypia (nuclear enlargement, overlap, pleomorphism or mitotic figures) is seen in up to one quarter of cases and, rarely, may be so severe that malignancy cannot be ruled out. Epithelial atypia is exaggerated with chemotherapy and radio- therapy and anabolic drug abuse [127, 128]. FNAC of male breast carcinoma, on the other hand, is identical to its female counterpart. Florid duct hyperplasia and atypia seen in gynecomastia necessitate a higher threshold for cytologic interpretation of malignancy in males [126]. Helpful distinguishing features are cohesiveness of cells, a lack of single malignant cells, the absence of macronuclei and the presence of ME cells in florid gynecomastia. A detailed clinical history including drug and radiation therapy is helpful. In some aspirates, however, the distinction between benign and malignant cannot be made and a C3 or $\mathrm{C} 4$ diagnosis is unavoidable. Clinical correlation and or biopsy should be recommended.

\section{Conclusion}

Inconclusive and erroneous FNAs of breast due to the 'true gray zone' are rare. The majority are due to overlapping cytologic features of some of the benign and malignant conditions we have described. The rest are due to rare conditions not necessarily familiar to practising pathologists. We described the FNAC of the common and rare lesions, pointing out the features that may help pathologists attain the correct diagnoses.

The original data from AUBMC was exempt from the local institutional review board. It was considered QI/QA data.

\section{Acknowledgements}

The authors acknowledge the efforts of Rami James Aoun for his help in the literature search and Dr. Mark Jabbour for his help in editing.

References $\quad 1$ Simsir A, Rapkiewicz A, Cangiarella J: Current utilization of breast FNA in a cytology practice. Diagn Cytopathol 2009;37:140-142.

-2 Simsir A, Cangiarella J, MD: Challenging breast lesions: pitfalls and limitations of fineneedle aspiration and the role of core biopsy in specific lesions. Diagn Cytopathol 2012;40: 262-272.

3 Rosa M, Mohammadi A, Masood S: The value of fine needle aspiration biopsy in the diagnosis and prognostic assessment of palpable breast lesions. Diagn Cytopathol 2012;40:2634.

$\checkmark 4$ National Cancer Institute Fine-Needle Aspiration of Breast Workshop Subcommittees: The uniform approach to breast fine-needle aspiration biopsy. Diagn Cytopathol 1997;16: 295-311. 
5 Bibbo M, Wilbur D: Breast; in: Comprehensive Cytopathology, ed 3. Philadelphia, Saunders Elsevier, 2008, p 715.

6 Sidawy M, Ali S: Fine Needle Aspiration Cytology; in Goldblum JR (ed): A volume in the series: Foundations in Diagnostic Pathology. Philadelphia, Churchill Livingstone, 2007.

7 Eckert R, Howell LP: Number, size, and composition of cell clusters as related to breast FNA adequacy. Diagn Cytopathol 1999;21: 105-111.

-8 Petersen JL, Koolman-Schellekens MA, van de Peppel-van de Ham T, van Heerde P: Atypia in fine-needle aspiration cytology of the breast: a histologic follow-up study of 301 cases. Semin Diagn Pathol 1989;6:126-134.

9 Al-Kaisi N: The spectrum of the 'gray zone' in breast cytology. A review of 186 cases of atypical and suspicious cytology. Acta Cytol 1994 38:898-908

10 Chaiwun B, Sukhamwang N, Lekawanvijit S, Sukapan K, Rangdaeng S, Muttarak M, Thorner PS: Atypical and suspicious categories in fine needle aspiration cytology of the breast: histological and mammographical correlation and clinical significance. Singapore Med J 2005;46:706.

11 Deb RA, Matthews P, Elston CW, Ellis IO, Pinder SE: An audit of 'equivocal' (C3) and 'suspicious' (C4) categories in fine needle aspiration cytology of the breast. Cytopathology 2001;12:219-226

12 Bibbo M, Scheiber M, Cajulis R, Keebler CM, Wied GL, Dowlatshahi K: Stereotaxic fine needle aspiration cytology of clinically occult malignant and premalignant breast lesions. Acta Cytol 1988;32:193-201.

-13 Kanhoush R, Jorda M, Gomez-Fernandez C, Wang $H$, Mirzabeigi M, Ghorab Z, GanjeiAzar P: 'Atypical' and 'suspicious' diagnoses in breast aspiration cytology. Cancer 2004 102:164-167.

14 Willis SL, Ramzy I: Analysis of false results in a series of 835 fine needle aspirates of breast lesions. Acta Cytol 1995;39:858-864.

15 Howell LP: Equivocal diagnoses in breast aspiration biopsy cytology: sources of uncertainty and the role of 'atypical/indeterminate' terminology. Diagn Cytopathol 1999;21:217222.

16 Sneige N: Fine-needle aspiration of the breast: a review of 1,995 cases with emphasis on diagnostic pitfalls. Diagn Cytopathol 1993;9: 106-112.

17 Layfield LJ, Dodd LG: Cytologically low grade malignancies: an important interpretative pitfall responsible for false negative diagnoses in fine-needle aspiration of the breast. Diagn Cytopathol 1996;15:250-259.

18 Ishikawa T, Hamaguchi Y, Tanabe M, Momiyama N, Chishima T, Nakatani Y, Nozawa A, Sasaki T, Kitamura H, Shimada H: False-positive and false-negative cases of fine-needle aspiration cytology for palpable breast lesions. Breast Cancer 2007;14:388-392.
19 Nggada HA, Tahir MB, Musa AB, Gali BM, Mayun AA, Pindiga UH, Yawe KD, Khalil MI: Correlation between histopathologic and fine needle aspiration cytology diagnosis of palpable breast lesions: a five-year review. Afr J Med Med Sci 2007;36:295-298.

-20 O’Neil S, Castelli M, Gattuso P, Kluskens L, Madsen K, Aranha G: Fine-needle aspiration of 697 palpable breast lesions with histopathologic correlation. Surgery 1997;122:824828.

21 Feichter GE, Haberthür F, Gobat S, Dalquen P: Breast cytology. Statistical analysis and cytohistologic correlations. Acta Cytol 1997;41: 327-332.

22 Choi YD, Choi YH, Lee JH, Nam JH, Juhng SW, Choi C: Analysis of fine needle aspiration cytology of the breast: a review of 1,297 cases and correlation with histologic diagnoses. Acta Cytol 2004;48:801-806

23 Jamal AA, Mansoor I: Analysis of false positive and false negative cytological diagnosis of breast lesions. Saudi Med J 2001;22:67-71.

24 Kline TS: Masquerades of malignancy: a review of 4,241 aspirates from the breast. Acta Cytol 1981;25:263-266.

25 Mooney EE, Seigler HF, Layfield LJ: Reporting fine-needle aspirates of breast: a survey of preferences among surgeons. Diagn Cytopathol 1998; 19:317-320.

26 Petersen JL, Thunnissen FB, van Heerde P: Fine needle aspiration cytology of radiationinduced changes in nonneoplastic breast lesions. Possible pitfalls in cytodiagnosis. Acta Cytol 1989;33:176-180.

27 Dornfeld JM, Thompson SK, Shurbaji MS: Radiation-induced changes in the breast: a potential diagnostic pitfall on fine-needle aspiration. Diagn Cytopathol 1992;8:79-80; discussion 80-1.

28 Filomena CA, Jordan AG, Ehya H: Needle aspiration cytology of the irradiated breast. Diagn Cytopathol 1992;8:327-332.

29 Mitre BK, Kanbour AI, Mauser N: Fine needle aspiration biopsy of breast carcinoma in pregnancy and lactation. Acta Cytol 1997;41: $1121-1130$

30 Novotny DB, Maygarden SJ, Shermer RW, Frable WJ: Fine needle aspiration of benign and malignant breast masses associated with pregnancy. Acta Cytol 1991;35:676-686.

31 Grenko RT, Lee KP, Lee KR: Fine needle aspiration cytology of lactating adenoma of the breast. A comparative light microscopic and morphometric study. Acta Cytol 1990;34:2126.

32 Gupta RK, McHutchison AG, Dowle CS, Simpson JS: Fine-needle aspiration cytodiagnosis of breast masses in pregnant and lactating women and its impact on management. Diagn Cytopathol 1993;9:156-159.

33 Choudhury M, Singal MK: Lactating adenoma - cytomorphologic study with review of literature. Indian J Pathol Microbiol 2001;44: 445-448.
4 Mehrotra R: Fine needle aspiration diagnosis of tuberculous mastitis. Indian J Pathol Microbiol 2004;47:377-380.

- 35 Gupta D, Rajwanshi A, Gupta SK, Nijhawan R, Saran RK, Singh R: Fine needle aspiration cytology in the diagnosis of tuberculous mastitis. Acta Cytol 1999;43:191-194.

36 Martínez-Parra D, Nevado-Santos M, Meléndez-Guerrero B, García-Solano J, HierroGuilmain CC, Pérez-Guillermo M: Utility of fine-needle aspiration in the diagnosis of granulomatous lesions of the breast. Diagn Cytopathol 1997;17:108-114.

37 Gupta RK: Fine needle aspiration cytology of granulomatous mastitis: a study of 18 cases. Acta Cytol 2010;54:138-141.

- 38 Poniecka AW, Krasuski P, Gal E, Lubin J, Howard L, Poppiti RJ: Granulomatous inflammation of the breast in a pregnant woman: report of a case with fine needle aspiration diagnosis. Acta Cytol 2001;45:797-801.

-39 Farmer C, Stanley MW, Bardales RH, Korourian S, Shah H, Bradsher R, Klimberg VS: Mycoses of the breast: diagnosis by fine-needle aspiration. Diagn Cytopathol 1995;12:51-55.

40 Adeniran A, Al-Ahmadie H, Mahoney MC, Robinson-Smith TM: Granular cell tumor of the breast: a series of 17 cases and review of the literature. Breast J 2004;10:528-531.

41 DeMay RM, Kay S: Granular cell tumor of the breast. Pathol Annu 1984;2:121-148.

-42 Ingram DL, Mossler JA, Snowhite J, Leight GS, McCarty KS Jr: Granular cell tumors of the breast. Steroid receptor analysis and localization of carcinoembryonic antigen, myoglobin, and S100 protein. Arch Pathol Lab Med 1984;108:897-901.

43 Strobel SL, Shah NT, Lucas JG, Tuttle SE: Granular-cell tumor of the breast. A cytologic, immunohistochemical and ultrastructural study of two cases. Acta Cytol 1985;29:598601.

44 Simsir A, Cangiarella J: Challenging breast lesions: pitfalls and limitations of fine-needle aspiration and the role of core biopsy in specific lesions. Diagn Cytopathol 2012;40:262272

45 Kollur SM, El Hag IA. FNA of breast fibroadenoma: Observer variability and review of cytomorphology with cytohistologic correlation. Cytopathology 2006;17:239-244.

46 Stanley MW, Tani EM, Skoog L: Fine needle aspiration of fibroadenomas of the breast with atypia: a spectrum including cases that cytologically mimic carcinoma. Diagn Cytopathol 1990;6:375-382.

47 Simsir A, Waisman J, Cangiarela J: Fibroadenomas with atypia: causes of under- and overdiagnosis by aspiration biopsy. Diagn Cytopathol 2001;25:278-284.

-48 Benoit JL, Kara R, McGregor SE, Duggan MA Fibroadenoma of the breast: diagnostic pitfalls of fine needle aspiration. Diagn Cytopathol 1992;8:643-648. 
49 Rogers LA, Lee KR: Breast carcinoma simulating fibroadenoma or fibrocystic change by fine-needle aspiration. A study of 16 cases. Am J Clin Pathol 1992;98:155-160.

-50 Lopez-Ferre P, Jimenez-Heffernan JA, Vicandi B, Orthega L, Viguer JM: Fine needle aspiration of the breast fibroadenoma. A cytohistologic correlation study of 405 cases. Acta Cytol 1999;43:579-586.

51 Shabb NS: Phyllodes tumor. Fine needle aspiration cytology of eight cases. Acta Cytol 1997;41:321-326.

-52 Krishnamurthy S, Ashfaq R, Shin HJ, Sneige $\mathrm{N}$ : Distinction of Phyllodes tumor from fibroadenoma: a reappraisal of an old problem. Cancer 2000;90:342-349.

53 Bhattarai S, Kapila K, Verma K: Phyllodes tumor of the breast. A cytohistologic study of 80 cases. Acta Cytol 2000;44:790-796.

54 Dusenbery D, Frable WJ: Fine needle aspiration cytology of Phyllodes tumor. Potential diagnostic pitfalls. Acta Cytol 1992;36:215221.

55 Saad RS, Richmond L, Nofech-Mozes S, Ghorab Z: Fine-needle aspiration biopsy of breast adenomyoepithelioma: a potential false positive pitfall and presence of intranuclear cytoplasmic inclusions. Diagn Cytopathol 2012; 40:1005-1009.

-56 Iyengar P, Ali SZ, Brogi E: Fine-needle aspiration cytology of mammary adenomyoepithelioma: a study of 12 patients. Cancer 2006; 108:250-256.

-57 Mercado CL, Toth H K, Axelrod D, Cangriella J: Fine-needle aspiration biopsy of benign adenomyoepithleioma of the breast. Radiologic and pathologic correlation in four cases. Diagn Cytopathol 2007;35:690-694.

-58 Aydin O, Cinel L, Egilmez R, Ocal K, Ozer C: Adenomyoepithlioma of the breast. Diagn Cytopathol 2001;25:194-196.

-59 Kurashina M: Fine-needle aspiration cytology of benign and malignant adenomyoepithelioma: report of two cases. Diagn Cytopathol 2002;26:29-34.

60 Ng WK: Adenomyoepithelioma of the breast. A review of three cases with reappraisal of the fine needle aspiration biopsy findings. Acta Cytol 2002;46:317-324.

61 Chang A, Bassett L, Bose S: Adenomyoepithelioma of the breast: a cytologic dilemma. Report of a case and review of the literature. $\mathrm{Di}$ agn Cytopathol 2002:26:191-196.

-62 Lee WY: Fine needle aspiration cytology of adenomyoepithelioma of the breast: a case indistinguishable from Phyllodes tumor in cytologic findings and clinical behavior. Acta Cytol 2000;44:488-490.

63 Laforga JB, Aranda FI, Sevilla F: Adenomyoepithelioma of the breast: report of two cases with prominent cystic changes and intranuclear inclusions. Diagn Cytopathol 1998;19: 55-58.

64 Niemann TH, Benda JA, Cohen MB: Adenomyoepithelioma of the breast: fine-needle aspiration biopsy and histologic findings. Diagn Cytopathol 1995;12:245-250.
65 Nilsson B, Wee A, Rauff A, Raju GC: Adenomyoepithelioma of the breast. Report of a case with fine needle aspiration cytology and histologic, immunohistochemical and ultrastructural correlation. Acta Cytol 1994;38: 431-434.

66 Valente PT, Stuckey JH: Fine-needle aspiration cytology of mammary adenomyoepithelioma: report of a case with intranuclear cytoplasmic inclusions. Diagn Cytopathol 1994; 10:165-168.

67 Harada O, Hoe R, Lin J, Thike AA, Jara-Lazaro AR, Petersson F, Tan $\mathrm{PH}$ : Intranuclear inclusions in epithelial cells of benign proliferative breast lesions. J Clin Pathol 2011;64:77680.

68 Iwa N, Baba M, Kanai T, Kobayashi TK, Yutani C: Presence of intranuclear cytoplasmic inclusions and cytoplasmic eosinophilic granules diagnosed by fine needle aspiration cytology in male breast cancer. Diagn Cytopathol 2009;37:143-145.

69 Landeyro J, Díaz ML, Raventós A, Vadillo J, Martínez MS: Cytological diagnostic clues in fine needle aspiration of breast myofibroblastoma: a case report. Diagn Cytopathol 2012; 40:1107-1111.

-70 Klopcic U, Lamovec J, Luzar B: Fine needle aspiration biopsy of primary breast myxofibrosarcoma: a case report. Acta Cytol 2009; 53:109-112.

71 Sneige N, Staerkel GA: Fine-needle aspiration cytology of ductal hyperplasia with and without atypia and ductal carcinoma in situ. Hum Pathol 1994;25:485-492.

72 McKee GT, Tildsley G, Hammond S: Cytologic diagnosis and grading of ductal carcinoma in situ. Cancer 1999;87:203-209.

73 Cangiarella J, Waisman J, Simsir A: Cytologic findings with histologic correlation in 43 cases of mammary intraductal adenocarcinoma diagnosed by aspiration biopsy. Acta Cytol 2003;47:965-972.

74 Sidawy MK, Stoler MH, Frable WJ, Frost AR, Masood S, Miller TR, Silverberg SG, Sneige N, Wang $\mathrm{HH}$ : Interobserver variability in the classification of proliferative breast lesions by fine-needle aspiration: results of the Papanicolaou Society of Cytopathology study. Diagn Cytopathol 1998;18:150-165.

75 Lilleng R, Hagmar BM, Farrants G: Lowgrade cribriform ductal carcinoma in situ of the breast. Fine needle aspiration cytology in three cases. Acta Cytol 1992;36:48-54.

76 Sauer T, Lømo J, Garred O, Naess O: Cytologic features of ductal carcinoma in situ in fine-needle aspiration of the breast mirror the histopathologic growth pattern heterogeneity and grading. Cancer 2005;105:21-27.

77 Silverman JF, Masood S, Ducatman BS, Wang $\mathrm{HH}$, Sneige N: Can FNA biopsy separate atypical hyperplasia, carcinoma in situ, and invasive carcinoma of the breast? Cytomorphologic criteria and limitations in diagnosis. Diagn Cytopathol 1993;9:713-728.
78 Abendroth CS, Wang $\mathrm{HH}$, Ducatman BS: Comparative features of carcinoma in situ and atypical ductal hyperplasia of the breast on fine-needle aspiration biopsy specimens. Am J Clin Pathol 1991;96:654-659.

79 Thomas PA, Raab SS, Cohen MB: Is the fineneedle aspiration biopsy diagnosis of proliferative breast disease feasible? Diagn Cytopathol 1994;11:301-306.

80 Cho EY, Oh YL: Fine needle aspiration cytology of sclerosing adenosis of the breast. Acta Cytol 2001;45:353-359.

81 Kundu UR, Guo M, Landon G, Wu Y, Sneige N, Gong Y: Fine-needle aspiration cytology of sclerosing adenosis of the breast: a retrospective review of cytologic features in conjunction with corresponding histologic features and radiologic findings. Am J Clin Pathol 2012;138:96-102.

82 Khirwadkar N, Clark AH: Fine needle aspiration cytology of tubular carcinoma of the breast. Acta Cytol 2005;49:344-345.

83 Cangiarella J, Waisman J, Shapiro RL, Simsir A: Cytologic features of tubular adenocarcinoma of the breast by aspiration biopsy. Diagn Cytopathol 2001;25:311-315.

84 Gupta RK, Dowle CS: Fine needle aspiration cytology of tubular carcinoma of the breast. Acta Cytol 1997;41:1139-1143.

85 Dei Tos AP, Della Giustina D, De Martin V, Della Libera D, Bittesini L: Aspiration biopsy cytology of tubular carcinoma of the breast. Diagn Cytopathol 1994;11:146-150.

86 Bondeson L, Lindholm K: Aspiration cytology of tubular breast carcinoma. Acta Cytol 1990;34:15-20.

87 Bonzanini M, Gilioli E, Brancato B, Pellegrini M, Mauri MF, Dalla Palma P: Cytologic features of 22 radial scar/complex sclerosing lesions of the breast, three of which associated with carcinoma: clinical, mammographic, and histologic correlation. Diagn Cytopathol 1997;17:353-362.

88 Greenberg ML, Camaris C, Psarianos T, Ung $\mathrm{OA}$, Lee WB: Is there a role for fine-needle aspiration in radial scar/complex sclerosing lesions of the breast? Diagn Cytopathol 1997; 16:537-542.

89 Lamb J, McGoogan E: Fine needle aspiration cytology of breast in invasive carcinoma of tubular type and in radial scar/complex sclerosing lesions. Cytopathology 1994;5:17-26.

$>90$ Field A, Mak A: The fine needle aspiration biopsy diagnostic criteria of proliferative breast lesions: a retrospective statistical analysis of criteria for papillomas and radial scar lesions. Diagn Cytopathol 2007;35:386-397.

91 de la Torre M, Lindholm K, Lindgren A: Fine needle aspiration cytology of tubular breast carcinoma and radial scar. Acta Cytol 1994; 38:884-890.

92 Mak A, Field AS: Positive predictive value of the breast FNAB diagnoses of epithelial hyperplasia with atypia, papilloma, and radial scar. Diagn Cytopathol 2006;34:818-823. 
93 Ng WK: Fine needle aspiration cytology of invasive cribriform carcinoma of the breast with osteoclastlike giant cells: a case report. Acta Cytol 2001;45:593-598.

\$4 Cai G, Simsir A, Cangiarella J: Invasive mammary carcinoma with osteoclast-like giant cells diagnosed by fine-needle aspiration biopsy: review of the cytologic literature and distinction from other mammary lesions containing giant cells. Diagn Cytopathol 2004;30:396-400.

95 Phillipson J, Ostrzega N: Fine needle aspiration of invasive cribriform carcinoma with benign osteoclastlike giant cells of histiocytic origin. A case report. Acta Cytol 1994;38: 479-482.

$\$ 96$ Vicandi B, Jiménez-Heffernan JA, LópezFerrer P, Hardisson D, Pérez-Campos A, González-Peramato P, Viguer JM: Fine needle aspiration cytology of mammary carcinoma with osteoclast-like giant cells. Cytopathology 2004;15:321-325.

$\$ 97$ Saqi A, Mercado CL, Hamele-Bena D: Adenoid cystic carcinoma of the breast diagnosed by fine-needle aspiration. Diagn Cytopathol 2004;30:271-274.

98 Kasagawa T, Suzuki M, Doki T, Fujimori T, Itami M, Takenouchi T, Yamamoto N: Two cases of adenoid cystic carcinoma: preoperative cytological findings were useful in determining treatment strategy. Breast Cancer 2006;13:112-116.

-99 Gupta RK, Green C, Naran S, Lallu S, Fauck R, Dowle C, Simpson J: Fine-needle aspiration cytology of adenoid cystic carcinoma of the breast. Diagn Cytopathol 1999;20:8284.

100 Stanley MW, Tani EM, Rutquist LE, Skoog L: Adenoid cystic carcinoma of the breast: diagnosis by fine-needle aspiration. Diagn Cytopathol 1993;9:184-187.

101 Duane GB, Kanter MH, Branigan T, Chang C: A morphologic and morphometric study of cells from colloid carcinoma of the breast obtained by fine needle aspiration. Distinction from other breast lesions. Acta Cytol 1987;31:742-750.

102 Fisher CJ, Millis RR: A mucocoele-like tumour of the breast associated with both atypical ductal hyperplasia and mucoid carcinoma. Histopathology 1992;21:69-71.

103 Ro JY, Sneige N, Sahin AA, Silva EG, del Junco GW, Ayala AG: Mucocelelike tumor of the breast associated with atypical ductal hyperplasia or mucinous carcinoma. A clinicopathologic study of seven cases. Arch Pathol Lab Med 1991;115:137-140.
104 Stanley MW, Tani EM, Skoog L: Mucinous breast carcinoma and mixed mucinous-infiltrating ductal carcinoma: a comparative cytologic study. Diagn Cytopathol 1989;5: 134-138.

105 Weaver MG, Abdul-Karim FW, al-Kaisi N: Mucinous lesions of the breast. A pathological continuum. Pathol Res Pract 1993;189: 873-876.

106 Simsir A, Waisman J, Thorner K, Cangiarella J: Mammary lesions diagnosed as 'papillary' by aspiration biopsy: 70 cases with follow-up. Cancer 2003;99:156-165.

107 Michael CW, Buschmann B: Can true papillary neoplasms of breast and their mimickers be accurately classified by cytology? Cancer 2002;96:92-100.

108 Ishihara A, Kobayashi TK: Infarcted intraductal papilloma of the breast: cytologic features with stage of infarction. Diagn Cytopathol 2006;34:373-376.

109 Greenberg ML, Middleton PD, Bilous AM: Infarcted intraduct papilloma diagnosed by fine-needle biopsy: a cytologic, clinical, and mammographic pitfall. Diagn Cytopathol 1994;11:188-191.

110 Jayaram G, Elsayed EM, Yaccob RB: Papillary breast lesions diagnosed on cytology. Profile of 65 cases. Acta Cytol 2007;51:3-8.

111 Haji BE, Das DK, Al-Ayadhy B, Pathan SK, George SG, Mallik MK, Abdeen M: Fineneedle aspiration cytologic features of four special types of breast cancers: mucinous, medullary, apocrine, and papillary. Diagn Cytopathol 2007;35:408-416.

-112 Bardales RH, Suhrland MJ, Stanley MW: Papillary neoplasms of the breast: fine-needle aspiration findings in cystic and solid cases. Diagn Cytopathol 1994;10:336-341.

-113 Abd el-All HS: Breast spindle cell tumours: about eight cases. Diagn Pathol 2006;1:13.

-114 Álvarez-Rodriguez F, Gimeno-Aranguez M, López-Varela C, González-Peramato P, Tortoledo-Bruni A, Rodríguez-Costa J, Perna C, Jiménez-Heffernan JA: Fine-needle aspiration cytology of mammary myofibroblastoma: a report of six cases. Acta Cytol 2012;56:501-505.

115 Magro G: Mammary myofibroblastoma: a tumor with a wide morphologic spectrum. Arch Pathol Lab Med 2008;132:1813-1820.

116 Gobbi H, Tse G, Page DL, Olson SJ, Jensen RA, Simpson JF: Reactive spindle cell nodules of the breast after core biopsy or fineneedle aspiration. Am J Clin Pathol 2000; 113:288-294.

117 Garijo MF, Val-Bernal JF, Vega A, Val D: Postoperative spindle cell nodule of the breast: pseudosarcomatous myofibroblastic proliferation following endo-surgery. Pathol Int 2008;58:787-791.
18 Lui PC, Tse GM, Tan PH, Jayaram G, Putti TC, Chaiwun B, Chan NH, Lau PP, Mak KL, Khin AT: Fine-needle aspiration cytology of metaplastic carcinoma of the breast. J Clin Pathol 2007;60:529-533.

119 Chhieng DC, Cangiarella JF, Waisman J, Fernandez G, Cohen JM: Fine-needle aspiration cytology of spindle cell lesions of the breast. Cancer 1999;87:359-371.

120 Nogueira M, André S, Mendonça E: Metaplastic carcinomas of the breast - fine needle aspiration (FNA) cytology findings. $\mathrm{Cy}-$ topathology 1998;9:291-300.

121 Davis WG, Hennessy B, Babiera G, Hunt K, Valero V, Buchholz TA, Sneige N, Gilcrease MZ: Metaplastic sarcomatoid carcinoma of the breast with absent or minimal overt invasive carcinomatous component: a misnomer. Am J Surg Pathol 2005;29:1456-1463.

122 Rosa M, Masood S: Cytomorphology of male breast lesions: diagnostic pitfalls and clinical implications. Diagn Cytopathol 2012;40:179-184

123 Singh R, Anshu, Sharma SM, Gangane N: Spectrum of male breast lesions diagnosed by fine needle aspiration cytology: a 5 -year experience at a tertiary care rural hospital in central India. Diagn Cytopathol 2012;40: 113-117.

124 Westenend PJ, Jobse C: Evaluation of fineneedle aspiration cytology of breast masses in males. Cancer 2002:96:101-104.

125 Kapila K, Verma K: Cytomorphological spectrum in gynaecomastia: a study of 389 cases. Cytopathology 2002;13:300-308.

126 Siddiqui MT, Zakowski MF, Ashfaq R, Ali SZ: Breast masses in males: multi-institutional experience on fine-needle aspiration. Diagn Cytopathol 2002;26:87-91.

127 Amrikachi M, Green LK, Rone R, Ramzy I: Gynecomastia: cytologic features and diagnostic pitfalls in fine needle aspirates. Acta Cytol 2001;45:948-952.

128 Pinedo F, Vargas J, de Agustín P, Garzón A, Pérez-Barrios A, Ballestín C: Epithelial atypia in gynecomastia induced by chemotherapeutic drugs. A possible pitfall in fine needle aspiration biopsy. Acta Cytol 1991; 35:229-233.

129 Martin-Bates E, Krausz T, Phillips I: Evaluation of fine needle aspiration of the male breast for the diagnosis of gynaecomastia. Cytopathology 1990;1:79-85.

130 Russin VL, Lachowicz C, Kline TS: Male breast lesions: gynecomastia and its distinction from carcinoma by aspiration biopsy cytology. Diagn Cytopathol 1989;5:243247.
Inconclusive/Erroneous FNAs of Breast: Review 